Review

\title{
Reproductive Chances of Men with Azoospermia Due to Spermatogenic Dysfunction
}

\author{
Caroline Kang ${ }^{+}\left(\mathbb{D}\right.$, Nahid Punjani ${ }^{+}(\mathbb{D})$ and Peter N. Schlegel $* \mathbb{( B )}$ \\ Department of Urology, Weill Cornell Medical College, New York, NY 10021, USA; \\ cak4005@med.cornell.edu (C.K.); nap4001@med.cornell.edu (N.P.) \\ * Correspondence: pnschleg@med.cornell.edu \\ + Equal contribution.
}

check for

updates

Citation: Kang, C.; Punjani, N.; Schlegel, P.N. Reproductive Chances of Men with Azoospermia Due to Spermatogenic Dysfunction. J. Clin. Med. 2021, 10, 1400. https://doi.org/ $10.3390 /$ jcm 10071400

Academic Editors: Giovanni M. Colpi and Ettore Caroppo

Received: 4 March 2021

Accepted: 26 March 2021

Published: 31 March 2021

Publisher's Note: MDPI stays neutral with regard to jurisdictional claims in published maps and institutional affiliations.

Copyright: (c) 2021 by the authors. Licensee MDPI, Basel, Switzerland. This article is an open access article distributed under the terms and conditions of the Creative Commons Attribution (CC BY) license (https:// creativecommons.org/licenses/by/ $4.0 /)$.

\begin{abstract}
Non-obstructive azoospermia (NOA), or lack of sperm in the ejaculate due to spermatogenic dysfunction, is the most severe form of infertility. Men with this form of infertility should be evaluated prior to treatment, as there are various underlying etiologies for NOA. While a significant proportion of NOA men have idiopathic spermatogenic dysfunction, known etiologies including genetic disorders, hormonal anomalies, structural abnormalities, chemotherapy or radiation treatment, infection and inflammation may substantively affect the prognosis for successful treatment. Despite the underlying etiology for NOA, most of these infertile men are candidates for surgical sperm retrieval and subsequent use in intracytoplasmic sperm injection (ICSI). In this review, we describe common etiologies of NOA and clinical outcomes following surgical sperm retrieval and ICSI.
\end{abstract}

Keywords: non-obstructive azoospermia; infertility; intracytoplasmic sperm injection

\section{Introduction}

Infertility affects up to $15 \%$ of couples worldwide, with up to $50 \%$ of cases attributable to male factor infertility [1]. In a majority of cases, the precise etiology underlying infertility in the male partner remains unclear. A subset of men with infertility have no sperm in the ejaculate, known as azoospermia, which may further be classified into obstructive (OA) or non-obstructive azoospermia (NOA). The majority of cases of NOA are idiopathic, however some known etiologies include genetic disorders, chemotherapy or radiation, developmental or structural abnormalities, and hormonal imbalances (Table 1). Despite the etiology underlying the spermatogenic dysfunction resulting in NOA, sperm often can be surgically extracted from the testis for use in assisted reproductive technology (ART) with varying success. Intracytoplasmic sperm injection (ICSI) requires only a single spermatozoon for injection into an oocyte, and thus has improved the chances for men with NOA to conceive biological children. In this review, we discuss common etiologies for NOA and the reproductive outcomes for NOA men after surgical sperm retrieval and ICSI.

Table 1. Etiologies of non-obstructive azoospermia.

\begin{tabular}{cc}
\hline Etiology & Example \\
\hline Idiopathic & \\
Genetic/Chromosomal & Klinefelter syndrome, Y-chromosome microdeletions \\
Iatrogenic/Surgical & Chemotherapy, Radiation therapy \\
Developmental/Structural & Cryptorchidism/Orchidopexy, Varicocele \\
Hormonal & Kallmann syndrome, hypogonadotropic \\
& hypogonadism, hyperprolactinemia/prolactinoma \\
\hline
\end{tabular}

\section{Treatment of Non-Obstructive Azoospermia}

Effective management of infertility in men with NOA requires testicular sperm retrieval as well as ART in the form of ICSI. Since sperm retrieval involves finding one of 
the very limited sites of sperm production within a highly dysfunctional testis of a man with NOA, it is not surprising that the approach used for sperm retrieval can substantially affect the chance of obtaining sperm for fertility.

A wide variety of approaches have been used for attempted sperm retrieval including fine needle aspiration of the testis (testicular sperm aspiration; TESA), random biopsies of testicular tissue to identify foci of sperm production (testicular sperm extraction; "conventional" TESE) as well as directed testicular surgical sperm retrieval using a microsurgical approach (microdissection testicular sperm extraction; microTESE or mTESE).

Each of these methods were compared using a meta-analysis of published literature [2]. Although a recent meta-analysis reported no difference in sperm retrieval rates when comparing conventional TESE to microTESE, it is important to note that this analysis did not require comparative studies so the heterogeneous nature of NOA patients treated at different sites invalidated any meaningful comparison of surgical techniques [3]. The superiority of microTESE is not surprising, as the surgery directs sampling of testicular tissue to the largest seminiferous tubules, which are those most likely to contain sperm [4]. From a laboratory perspective, the microTESE approach is ideal, as it limits the amount of tissue that must be examined by the andrologist to identify sperm to that which is richest in sperm production. Typical search times to find sperm in isolated, dispersed testicular tissue specimens is only 3 to $5 \mathrm{~min}$ at experienced centers. Of note, microTESE, although an invasive surgical procedure, has less effect on testicular function than other approaches for sperm retrieval [4].

\section{Causes of Non-Obstructive Azoospermia}

NOA occurs secondary to the disruption of spermatogenesis within the testicular parenchyma. This disruption of sperm production is a common phenotype with various underlying etiologies. Although understanding the underlying etiology of azoospermia may help in prognosis and counseling, the precise mechanisms by which spermatogenesis is disrupted in these disorders are not well understood. Men with NOA have varying ranges of spermatogenic failure, and even in 30-60\% of those with severely dysfunctional histology (i.e., Sertoli Cell Only (SCO) or maturation arrest) small foci of spermatogenesis can be observed [5]. Furthermore, many other presumed idiopathic cases of NOA are likely to be caused by genetic abnormalities that are yet to be fully delineated.

\subsection{Hormonal Imbalances}

Men with hypogonadotropic hypogonadism $(\mathrm{HH})$ suffer from a lack of gonadotropin stimulation, resulting in failure of the testis to produce testosterone or sperm. The defect can be congenital (e.g., Kallmann syndrome, Prader-Willi syndrome) or acquired (e.g., secondary to pituitary tumor or exogenous steroid administration). The resultant phenotype of these men is lack of development of secondary sexual characteristics (with prepubertal phenotype) and infertility. Importantly, because the phenotype is caused by a lack of gonadotropin, treatment of these men with exogenous gonadotropins (e.g., human chorionic gonadotropin (hCG) and recombinant follicle-stimulating hormone (FSH)) can result in the appropriate development of secondary sexual characteristics (i.e., pubic hair development, testis growth, development of muscle mass) and sperm [6]. Men with $\mathrm{HH}$ typically do not require ICSI to achieve pregnancy as treatment with exogenous gonadotropins is highly effective in inducing spermatogenesis adequate to allow return of sperm to the ejaculate, which is associated with an increase in endogenous testosterone production [6].

Hyperprolactinemia, or elevated serum prolactin levels, is a rare etiology for azoospermia but clinically relevant. Prolactin is produced by the posterior pituitary and elevated levels can result from a prolactin-secreting adenoma (or prolactinoma) [7]. One study examining prolactin levels in infertile men observed increased prolactin levels in men with asthenozoospermia, oligozoospermia, and azoospermia [8]. Since hyperprolactinemia is typically effectively treated with medical therapy, it is rarely a cause for persistent NOA requiring surgical intervention. 


\subsection{Klinefelter Syndrome}

Klinefelter Syndrome (KS) is the most common sex chromosome aneuploidy in infertile men, with an estimated prevalence of approximately $10 \%$ in men with NOA [9]. This syndrome involves the addition of one or more extra X-chromosome(s), resulting most commonly in a 47,XXY karyotype [9-11]. KS is thought to occur secondary to chromosomal nondisjunction during meiosis [12,13]. Physical examination of KS men often reveals characteristic findings of tall stature, reduced testis size, reduced chest and facial hair, gynecomastia, eunuchoid appearance, wide hips, and narrow shoulders [13]. Small testis size is thought to occur due to fibrosis and hyalinization of the seminiferous tubules and is progressive through puberty and adult development $[14,15]$. Rare, small foci of spermatogenesis in the testes of KS men is hypothesized to be present due to the capability of XXY stem cells to undergo spermatogenesis, or more likely, mitotic errors within the XXY stem cell population resulting in diploid cells capable of completing the remaining spermatogenic process [16].

\subsection{Y-Chromosome Microdeletions}

One of the most common identifiable etiologies of NOA are microdeletions of the azoospermia factor (AZF) region of the $\mathrm{Y}$ chromosome, and up to $12 \%$ of men with NOA harbor AZF microdeletions [17]. There are three loci in the AZF region, which are designated $\mathrm{AZFa}, \mathrm{AZFb}$ and $\mathrm{AZF}$, and each locus contains various genes responsible for different aspects of spermatogenesis [18-20]. Microdeletions within AZFc are the most common (up to $80 \%$ ), whereas AZFa (up to $4 \%$ ) and AZFb (up to $5 \%$ ) are less common [21]. Polymerase chain reaction (PCR) is used to detect Y-chromosome microdeletions (YCMDs) as these chromosomal deletions are too small to detect by standard karyotype analysis. Current guidelines recommend testing for YCMD along with karyotype analysis in men with NOA or severe oligozoospermia $(<5$ million sperm $/ \mathrm{mL})$ [22]. Knowing the YCMD status in a man with severe infertility carries important prognostic information as the sperm retrieval rates (SRR) in men with complete AZFa and AZFb deletions is zero, whereas men with AZFc deletions can have SRR of approximately 50-60\% [23].

\subsection{Malignancy, Chemotherapy, and Radiation}

Malignancy and associated treatments such as chemotherapy and radiation are important causes of azoospermia as approximately $50 \%$ of men will be affected by cancer in their lifetime [24]. Chemotherapy targets rapidly dividing cells and testicular germ cells which are mitotically and meiotically active and are highly sensitive to these systemic agents [25]. DNA alkylating agents, as well as platinum-containing chemotherapy agents (such as cisplatin), cross-link DNA and are particularly harmful to spermatogonial stem cells and may result in permanent azoospermia $[26,27]$. Other chemotherapy agents, such as anthracyclines, antimetabolites, and topoisomerase inhibitors, typically are less gonadotoxic and result only in transient decreases in sperm count because differentiating spermatogonia, and not stem cells, are primarily affected [26]. The CED, or cyclophosphamide-equivalent dose, may be used to determine estimated alkylating agent exposure [28]. One study of adult childhood cancer survivors found that when the CED was less than $4000 \mathrm{mg} / \mathrm{m}^{2}$ men were normospermic, however there was substantial overlap in the CED values of normozoospermic, oligozoospermic, and azoospermic men [29]. Radiation therapy, on the other hand, may result in irreversible testicular damage secondary to the high radio-sensitivity of testicles [30]. Spermatogonial stem cells are highly sensitive to radiation and are adversely impacted even at low radiation doses $(0.1 \mathrm{~Gy})$, with permanent azoospermia typically occurring with doses of 16-20 Gy but reportedly occurring with radiation doses as low as 4 Gy $[25,31]$. Recovery of spermatogenesis after chemotherapy or radiation therapy depends on the chemotherapy agent used and cumulative chemotherapy or radiation dose [31].

Importantly, as the efficacy of cancer treatments has improved, the number of survivors has increased worldwide [24]. Therefore, strong recommendations from the Ameri- 
can Urological Association (AUA), American Society of Clinical Oncology (ASCO), and American Society for Reproductive Medicine (ASRM) have been made to counsel and refer patients for discussion of fertility preservation prior to initiating cancer treatments [32-34]. Additionally, men undergoing chemotherapy or radiation therapy should avoid pregnancy for a minimum of twelve months after completing treatment because of potentially mutagenic effects of the treatments on germ cells [34,35]. Finally, in men with persistent azoospermia after gonadotoxic chemotherapy or radiation treatment, testicular sperm extraction may be performed to harvest sperm for ART [34].

\subsection{Cryptorchidism}

Cryptorchidism, or undescended testis, is a well-known risk factor for male infertility and a common genitourinary finding. This disorder affects $1-9 \%$ of all male neonates worldwide, with approximately $3 \%$ of boys remaining cryptorchid at one year of age [36,37]. Semen abnormalities are observed in up to $30 \%$ of men with a history of unilateral cryptorchidism and up to $80 \%$ of men with a history of bilateral cryptorchidism [38]. Recommended treatment is orchidopexy, or fixation of the testis within the scrotum, and typically is performed early in life (by 18 months of age) to prevent future testicular dysfunction $[36,39,40]$. The majority of men with a history of cryptorchidism, either unilateral or bilateral, are fertile, however some may develop azoospermia secondary to iatrogenic injury to the testis or testicular vasculature during orchidopexy, or baseline underlying severe spermatogenic dysfunction. For men with NOA secondary to cryptorchidism, testicular sperm extraction is generally favorable with success in the majority of these patients [41-46].

\subsection{Varicocele}

Varicoceles are a common cause of infertility, found in at least $5 \%$ of men with NOA, and the most common cause of secondary infertility $[47,48]$. Varicoceles are dilated veins (spermatic and pampiniform plexus veins) within the spermatic cord and may result in subsequent testicular dysfunction [49]. Different mechanisms of testicular dysfunction in men with varicoceles have been proposed, including testicular parenchymal hyperthermia, blood-testis barrier dysfunction, and testicular hypoxia [50]. The ultimate downstream effect is the generation of reactive oxygen species and damage to testicular cells [50-52]. Damage to Sertoli, Leydig, and germ cells can result in abnormal or decreased sperm production, as well as deficient testosterone production [49,53]. Although varicoceles clearly contribute to testicular dysfunction, a varicocele is unlikely to be the primary cause of NOA since only $5-10 \%$ of men with NOA and clinical varicocele will have enough sperm return to the ejaculate after varicocele repair to avoid testicular sperm extraction [54].

\subsection{Other Causes of NOA}

NOA may also be acquired for a wide variety of reasons including genitourinary infections, such as post-pubertal mumps orchitis, or various classes of medications. Common medication categories with documented negative impacts to fertility include exogenous testosterone or other androgen-modulating medications, psychiatric medications, and antihypertensive medications, which all have been documented to modulate the hormonal environment resulting in decreased or absent sperm production [55].

\section{Optimization of Sperm Production Prior to Surgical Retrieval}

Various abnormalities, including hormonal deficiencies and testicular dysfunction, may contribute to abnormal spermatogenesis and decreased or absent sperm production. The production of sperm requires adequate levels of (serum and intratesticular) testosterone, and the goal of optimization is to increase testosterone levels. Serum testosterone levels can be optimized prior to surgical sperm extraction by administration of hormone analogs and modulators, including gonadotropins, aromatase inhibitors (AI), and selective estrogen receptor modulators (SERM) (Table 2). Unfortunately, there is no high-level evi- 
dence to support use of medical therapy prior to sperm retrieval, despite many anecdotal applications of medical therapy prior to attempted sperm retrieval for NOA [22]. Certainly, it is conceptually appropriate to treat low testosterone levels in men with NOA. However, retrospective data from a large series of men with NOA suggest that the benefits of treatment are quite limited, with men receiving medical therapy to raise testosterone levels having SRR of 51\% (151/307) compared with men not receiving medical therapy prior to surgical intervention who had SRR of $61 \%(25 / 41)(p=0.31)$ [56].

Table 2. Medical therapy for hormonal optimization prior to sperm retrieval.

\begin{tabular}{ccc}
\hline Class & Medication Name & Dose \\
\hline AI & Anastrozole & $1 \mathrm{mg} /$ day \\
AI & Letrozole & $2.5 \mathrm{mg} /$ day \\
\hline Gonadotropin & hCG & $1500-3000 \mathrm{IU} 2 \times /$ week \\
Gonadotropin & rhFSH & $100-1500 \mathrm{IU} 2-3 \times /$ week \\
\hline SERM & Clomiphene Citrate & $25-50 \mathrm{mg} /$ day \\
SERM & Tamoxifen & $20 \mathrm{mg} /$ day \\
\hline
\end{tabular}

AI, aromatase inhibitor, SERM, selective estrogen receptor modulator; rhFSH, recombinant human folliclestimulating hormone; hCG, human chorionic gonadotropin; IU, international unit.

Medical therapy used to optimize testosterone levels aims to increase testosterone production and decrease estradiol levels. Elevated estradiol levels, typically greater than $60 \mathrm{pg} / \mathrm{mL}$, can suppress hypothalamic gonadotropin secretion and subsequently inhibit testosterone production [6]. Testosterone-to-estradiol (T:E) ratios are normally greater than 10 , and fertile men have a mean T:E ratio of approximately $15(14.5 \pm 1.2)[57,58]$. Men with infertility have lower T:E ratios, with NOA men typically in the range of $7(6.9 \pm 0.6)$ and men with KS approximately 5 (4.4 \pm 0.5$)$ [58-60]. Gonadotropins can stimulate testosterone production and spermatogenesis in men with low gonadotropin levels secondary to congenital or acquired disorders [60]. hCG may be used as an luteinizing hormone (LH) substitute alone or in combination with an FSH analog (recombinant human FSH (rhFSH) or human menopausal gonadotropin (hMG)) to stimulate testis growth, testosterone production, and spermatogenesis [60]. AIs, including anastrozole and letrozole, prevent the actions of aromatase, which is present in peripheral tissues, in converting testosterone to estrogen. AIs have been shown to be effective medical therapy to increase SRR in men with KS and in infertile, non-KS men with abnormal T:E ratios [61,62]. SERMs, such as clomiphene citrate and tamoxifen, provide benefits by inhibiting the negative feedback exerted on the hypothalamic-pituitary-testis (HPT) axis by estrogen. With decreased negative inhibition, higher levels of LH and FSH can be achieved, resulting in increased serum testosterone levels and improved sperm production. Several studies have demonstrated positive impacts on semen parameters in infertile men taking clomiphene citrate [63,64].

Repair of clinical varicoceles has been demonstrated to improve serum testosterone levels, as well as spermatogenesis in men with oligozoospermia [48]. After varicocele repair in men with NOA, the potential improvement of spermatogenesis may result in enhanced SRR, although there is no high-level evidence to support such intervention [54].

\section{Intracytoplasmic Sperm Injection for NOA}

Prior to the advent of ICSI, men with NOA had no means for conceiving biological children. ICSI was first introduced in 1992, and three years later, in 1995, sperm retrieved from an NOA patient was used successfully with ICSI $[65,66]$. Since the development of ICSI, numerous studies have been performed to examine factors that may predict or be associated with increased ICSI success.

\subsection{Predictors of ICSI Outcomes}

Limited pre-operative variables exist which predict success of SRR and ICSI. For predictors of SRR, patient age, serum hormone levels, and testicle size have been evaluated, 
however, conclusive evidence is lacking that any of these factors is predictive of successful sperm retrieval [67-69]. Testicular histopathology does provide some prognostic information for SRR, but it is not routinely recommended for diagnosis of NOA, as the diagnosis can be made clinically based on FSH $>7.6$ and testis length $<4.5 \mathrm{~cm}$ in about $90 \%$ of men with this condition $[22,68,70,71]$. Similarly, no clinical or biochemical factors have been found to be predictive of ICSI outcomes [3]. Additionally, testis histology has not been shown to significantly influence clinical outcomes after ICSI [71]. There may, however, be an association of the number of sperm found at time of surgical retrieval with the number of clinical pregnancies [72]. Further work is needed to determine if any preoperative factors, in conjunction with female factors, can predict ICSI outcomes.

\subsection{ICSI Outcomes in NOA Men}

Understanding clinical outcomes after ICSI are important when counseling men with NOA and their partners prior to surgical sperm retrieval. A study derived from the National Assisted Reproductive Technology Surveillance System (NASS) found that men with infertility (including non-azoospermic and azoospermic men) had a clinical pregnancy rate (CPR) of $48 \%$ and live birth rate (LBR) of $40 \%$, which was similar to rates in men with no infertility (CPR 44.9\%, LBR 36.5\%) [73]. A clear limitation of this study was that the various etiologies of male infertility were not specified or separately examined and thus, the CPR and LBR may not hold true for all etiologies of NOA. Although NOA men represent the most severe phenotype of those with male infertility, the majority of studies, similar to that previously described, have pooled men with NOA regardless of etiology which limits the overall generalizability of the data. A comprehensive summary of SRR, biochemical pregnancy rate (BCPR), CPR, and LBR from studies investigating ICSI outcomes between 1997 and 2020 in NOA men is presented in Table 3.

Table 3. Studies reporting intracytoplasmic sperm injection outcomes in men with non-obstructive azoospermia.

\begin{tabular}{|c|c|c|c|c|c|c|c|}
\hline Study & Year & NOA Etiology & $\begin{array}{c}\text { Sperm } \\
\text { Retrieval }\end{array}$ & SRR (\%) & $\begin{array}{c}\text { (BCPR (\%)) } \\
\text { CPR (\%) }\end{array}$ & LBR (\%) & MR (\%) \\
\hline $\begin{array}{c}\text { Fahmy et al. } \\
{[74]}\end{array}$ & 1997 & NR & cTESE & NR & $\begin{array}{l}(16.6) \\
19.2\end{array}$ & NR & NR \\
\hline $\begin{array}{l}\text { Friedler et al. } \\
\text { [75] }\end{array}$ & 1997 & NR & $\begin{array}{l}\text { TESA } \\
\text { TESE }\end{array}$ & 43.0 & 29.0 & NR & NR \\
\hline $\begin{array}{l}\text { Ben-Yosef } \\
\text { et al. [76] }\end{array}$ & 1999 & NR & TESE* & 60.0 & $21.7-27$ & $13.0-25.0$ & $6.7-8.7$ \\
\hline $\begin{array}{l}\text { Palermo } \\
\text { et al. [77] }\end{array}$ & 1999 & NR & mTESE & 63.9 & 49.1 & NR & 12.5 \\
\hline $\begin{array}{l}\text { Mercan et al. } \\
{[78]}\end{array}$ & 2000 & NR & $\begin{array}{l}\text { TESA } \\
\text { TESE }\end{array}$ & 64.4 & $29-46$ & NR & $20.7-24.2$ \\
\hline $\begin{array}{l}\text { Chan et al. } \\
\text { [79] }\end{array}$ & 2001 & Chemotherapy & $\begin{array}{l}\text { cTESE } \\
\text { mTESE }\end{array}$ & 45.0 & $\begin{array}{l}(44.5) \\
33.3\end{array}$ & 22.2 & NR \\
\hline $\begin{array}{l}\text { Damani } \\
\text { et al. [80] }\end{array}$ & 2002 & Chemotherapy & cTESE & 65.2 & 60.0 & 53.0 & NR \\
\hline $\begin{array}{l}\text { Friedler et al. } \\
\text { [81] }\end{array}$ & 2002 & NR & cTESE & $39.0-85.0$ & $16.0-19.0$ & $67.0-80.0$ & NR \\
\hline $\begin{array}{c}\text { Mátyás et al. } \\
\text { [82] }\end{array}$ & 2002 & NR & cTESE & 69.6 & 26.7 & NR & NR \\
\hline $\begin{array}{c}\text { Bailly et al. } \\
\text { [83] }\end{array}$ & 2003 & NR & cTESE & 35.0 & 18.0 & 81.8 & 9.0 \\
\hline
\end{tabular}


Table 3. Cont.

\begin{tabular}{|c|c|c|c|c|c|c|c|}
\hline Study & Year & NOA Etiology & $\begin{array}{c}\text { Sperm } \\
\text { Retrieval }\end{array}$ & SRR (\%) & $\begin{array}{c}(\operatorname{BCPR}(\%)) \\
\text { CPR }(\%)\end{array}$ & LBR (\%) & $\operatorname{MR}(\%)$ \\
\hline $\begin{array}{l}\text { Mansour } \\
\text { et al. [84] }\end{array}$ & 2003 & NR & cTESE & 56.1 & $13.6-24.1$ & NR & NR \\
\hline $\begin{array}{l}\text { Meseguer } \\
\text { et al. [85] }\end{array}$ & 2003 & Chemotherapy & cTESE & 41.7 & 20.0 & 20.0 & NR \\
\hline $\begin{array}{l}\text { Osmanagaoglu } \\
\text { et al. [86] }\end{array}$ & 2003 & NR & TESE* & NR & NR & 13.9 & NR \\
\hline $\begin{array}{c}\text { Raman } \\
\text { et al.-a [42] }\end{array}$ & 2003 & Cryptorchidism & $\begin{array}{l}\text { cTESE } \\
\text { mTESE }\end{array}$ & 74.0 & 46.0 & 43.0 & NR \\
\hline $\begin{array}{c}\text { Raman } \\
\text { et al.-b [42] }\end{array}$ & 2003 & NR & $\begin{array}{l}\text { cTESE } \\
\text { mTESE }\end{array}$ & 58.0 & 44.0 & 36.0 & 8.1 \\
\hline $\begin{array}{c}\text { Vernaeve } \\
\text { et al.-a [43] }\end{array}$ & 2004 & $\begin{array}{l}\text { NOA (excluded } \\
\text { cryptorchidism) }\end{array}$ & cTESE & $33.3 \%$ & $\begin{array}{l}(20.7) \\
10.9\end{array}$ & 10.9 & NR \\
\hline $\begin{array}{c}\text { Vernaeve } \\
\text { et al.-b [43] }\end{array}$ & 2004 & Cryptorchidism & cTESE & 51.9 & $\begin{array}{l}(28.1) \\
17.2\end{array}$ & 17.2 & NR \\
\hline $\begin{array}{l}\text { Aydos et al. } \\
\text { [87] }\end{array}$ & 2005 & $\begin{array}{l}\text { Cryptorchidism, } \\
\text { idiopathic, nontestis } \\
\text { cancer, RT, trauma, } \\
\text { mumps, orchitis, } \\
\text { chromosome } \\
\text { anomaly }\end{array}$ & mTESE & 57.0 & 36.0 & NR & NR \\
\hline $\begin{array}{l}\text { Giorgetti } \\
\text { et al. [88] }\end{array}$ & 2005 & NR & cTESE & 46.0 & 35.3 & $25.0-29.0$ & NR \\
\hline $\begin{array}{l}\text { Mitchell } \\
\text { et al. [89] }\end{array}$ & 2005 & NR & cTESE & $\mathrm{N} / \mathrm{A}$ & $8.7-26.7$ & $17.4-33.3$ & NR \\
\hline $\begin{array}{l}\text { Wu et al. } \\
\text { [90] }\end{array}$ & 2005 & NR & cTESE & 76.7 & $33.3-62.5$ & $33.3-41.7$ & $0-20.8$ \\
\hline $\begin{array}{l}\text { Everaert } \\
\text { et al. [91] }\end{array}$ & 2006 & NR & $\begin{array}{l}\text { MESA } \\
\text { mTESE }\end{array}$ & 35.4 & $\begin{array}{c}(13.2) \\
9.4\end{array}$ & 7.5 & NR \\
\hline $\begin{array}{l}\text { Hibi et al. } \\
\text { [92] }\end{array}$ & 2007 & Chemotherapy & mTESE & 60.0 & NR & 40.0 & NR \\
\hline $\begin{array}{l}\text { Mitchell } \\
\text { et al. [93] }\end{array}$ & 2007 & NR & cTESE & $\mathrm{N} / \mathrm{A}$ & 26.0 & 13.3 & NR \\
\hline $\begin{array}{c}\text { Kanto et al. } \\
\text { [94] }\end{array}$ & 2009 & NR & mTESE & 42.5 & 52.9 & NR & NR \\
\hline $\begin{array}{l}\text { Ravizzini } \\
\text { et al. [95] }\end{array}$ & 2008 & NR & mTESE & 57.1 & $\begin{array}{c}(50.0) \\
40.0\end{array}$ & 40.0 & NR \\
\hline $\begin{array}{l}\text { Ishikawa } \\
\text { et al. [96] }\end{array}$ & 2009 & NR & mTESE & $\mathrm{N} / \mathrm{A}$ & $\begin{array}{c}(36.8) \\
30.9\end{array}$ & 26.5 & NR \\
\hline $\begin{array}{c}\text { Wiser et al. } \\
\text { [44] }\end{array}$ & 2009 & Cryptorchidism & cTESE & 59.5 & $30.8-41.2$ & $75.0-80.0$ & NR \\
\hline $\begin{array}{c}\text { Yarali } \\
\text { et al.-a [97] }\end{array}$ & 2009 & non-KS & mTESE & 44.0 & $\begin{array}{c}(41.0) \\
33.0\end{array}$ & 26.0 & NR \\
\hline $\begin{array}{c}\text { Yarali } \\
\text { et al.—b [97] }\end{array}$ & 2009 & KS & mTESE & 56.0 & $\begin{array}{l}(61.0) \\
39.0\end{array}$ & 28.0 & NR \\
\hline
\end{tabular}


Table 3. Cont.

\begin{tabular}{|c|c|c|c|c|c|c|c|}
\hline Study & Year & NOA Etiology & $\begin{array}{c}\text { Sperm } \\
\text { Retrieval }\end{array}$ & SRR (\%) & $\begin{array}{c}(\text { BCPR }(\%)) \\
\text { CPR }(\%)\end{array}$ & LBR (\%) & MR (\%) \\
\hline $\begin{array}{l}\text { Boitrelle } \\
\text { et al. [98] }\end{array}$ & 2011 & $\begin{array}{l}\text { Cryptorchidism, KS, } \\
\text { YCMD, Y inversion, } \\
\text { malignancy, } \\
\text { idiopathic } \\
\text { chemotherapy/RT }\end{array}$ & cTESE & 53.2 & 42.7 & 37.0 & $\begin{array}{c}7.9 \\
5.3^{€}\end{array}$ \\
\hline $\begin{array}{c}\text { Hauser et al. } \\
\text { [99] }\end{array}$ & 2011 & $\begin{array}{c}\text { NOA + } \\
\text { cryptozoospermia }\end{array}$ & cTESE & $\mathrm{N} / \mathrm{A}$ & $\begin{array}{c}(19.1-42.9) \\
12.8-42.9\end{array}$ & $12.8-42.9$ & NR \\
\hline $\begin{array}{l}\text { Hsiao et al. } \\
\text { [100] }\end{array}$ & 2011 & Chemotherapy & mTESE & 37.0 & 50.0 & 42.0 & NR \\
\hline $\begin{array}{c}\text { Ashraf et al. } \\
\text { [101] }\end{array}$ & 2013 & NR & mTESE & 50.0 & 40.0 & NR & NR \\
\hline $\begin{array}{l}\text { Choi } \\
\text { et al.-a } \\
\text { [102] }\end{array}$ & 2013 & $\begin{array}{c}\mathrm{NOA}+\mathrm{AZFC} \\
\text { YCMD }\end{array}$ & cTESE & 21.0 & NR & 19.5 & NR \\
\hline $\begin{array}{l}\text { Choi } \\
\text { et al.-b } \\
\text { [102] }\end{array}$ & 2013 & AZFc YCMD & cTESE & 26.6 & NR & 24.3 & NR \\
\hline $\begin{array}{l}\text { Karacan } \\
\text { et al. [103] }\end{array}$ & 2013 & NR & mTESE & 54.9 & 31.3 & 28.9 & 7.6 \\
\hline $\begin{array}{c}\text { Arafa et al. } \\
\text { [104] }\end{array}$ & 2014 & $\begin{array}{c}\text { Familial and } \\
\text { non-familial } \\
\text { idiopathic NOA }\end{array}$ & mTESE & 37.4 & 13.9 & NR & NR \\
\hline $\begin{array}{l}\text { Esteves et al. } \\
\text { [105] }\end{array}$ & 2014 & NR & mTESE & 41.4 & 27.8 & 19.9 & 28.6 \\
\hline $\begin{array}{l}\text { Karacan } \\
\text { et al. [106] }\end{array}$ & 2014 & NR & mTESE & 48.9 & $16.6-30.7$ & $16.6-28.2$ & 8.3 \\
\hline $\begin{array}{l}\text { Aydin et al. } \\
\text { [107] }\end{array}$ & 2015 & NR & mTESE & 58.6 & 44.6 & NR & NR \\
\hline $\begin{array}{l}\text { Tsai et al. } \\
\text { [45] }\end{array}$ & 2015 & Cryptorchidism & TESE* & $\mathrm{N} / \mathrm{A}$ & 45.6 & 32.9 & 6.3 \\
\hline $\begin{array}{l}\text { Vloeberghs } \\
\text { et al. [108] }\end{array}$ & 2015 & NR & cTESE & 40.5 & $\begin{array}{l}(27.7-34) \\
21.7-26.7\end{array}$ & $20.6-25.3$ & NR \\
\hline $\begin{array}{l}\text { Ko et al. } \\
\text { [109] }\end{array}$ & 2016 & NR & $\begin{array}{l}\text { cTESE } \\
\text { mTESE }\end{array}$ & 44.9 & $\begin{array}{c}(37.5) \\
30\end{array}$ & 25.0 & NR \\
\hline $\begin{array}{l}\text { Alfano et al. } \\
\text { [110] }\end{array}$ & 2017 & Idiopathic NOA & mTESE & 48.9 & 21.7 & 13.0 & NR \\
\hline $\begin{array}{c}\text { Arafa } \\
\text { et al.-a } \\
{[111]}\end{array}$ & 2018 & $\begin{array}{l}\text { Idiopathic NOA + } \\
\text { AZFc YCMD }\end{array}$ & TESE* & 63.2 & 25.7 & NR & NR \\
\hline $\begin{array}{c}\text { Arafa } \\
\text { et al.-b b } \\
{[111]}\end{array}$ & 2018 & Idiopathic NOA & TESE* & 65.8 & 26.6 & NR & NR \\
\hline $\begin{array}{c}\text { Yu et al. } \\
\text { [112] }\end{array}$ & 2018 & NR & mTESE & 38.4 & $\begin{array}{c}(34.3) \\
49.1\end{array}$ & 24.6 & 20.7 \\
\hline
\end{tabular}


Table 3. Cont

\begin{tabular}{|c|c|c|c|c|c|c|c|}
\hline Study & Year & NOA Etiology & $\begin{array}{c}\text { Sperm } \\
\text { Retrieval }\end{array}$ & SRR (\%) & $\begin{array}{c}\text { (BCPR }(\%)) \\
\text { CPR }(\%)\end{array}$ & LBR (\%) & MR (\%) \\
\hline $\begin{array}{l}\text { Chen et al. } \\
\text { [41] }\end{array}$ & 2019 & $\begin{array}{l}\text { Idiopathic, KS, } \\
\text { YCMD, } \\
\text { cryptorchidism, } \\
\text { mumps orchitis, } \\
\text { chemotherapy }\end{array}$ & mTESE & 40.3 & $51.0-55.8$ & NR & NR \\
\hline $\begin{array}{c}\text { Yamaguchi } \\
\text { et al.—a } \\
\text { [113] }\end{array}$ & 2020 & $\begin{array}{c}\text { NOA (excluded } \\
\text { AZFc YCMD) }\end{array}$ & mTESE & 74.0 & 28.9 & NR & 20.2 \\
\hline $\begin{array}{c}\text { Yamaguchi } \\
\text { et al._b } \\
\text { [113] }\end{array}$ & 2020 & AZFc YCMD & mTESE & 20.4 & 24.7 & NR & 26.3 \\
\hline
\end{tabular}

AZFRc, azoospermia factor region deletion in locus c; SRR, sperm retrieval rate; BCPR, biochemical pregnancy rate (elevated serum hCG); CPR, clinical pregnancy rate (heartbeat or gestational sac detectable by ultrasound); LBR, live birth rate; MR, miscarriage rate; NOA, non-obstructive azoospermia; NR, not reported; TESA, testicular sperm aspiration; cTESE, conventional TESE; mTESE, microdissection TESE; TESE * - type of TESE not specified; $\epsilon$, ectopic pregnancy rate; KS, Klinefelter syndrome; YCMD, Y-chromosome microdeletion; RT, radiation therapy; MESA, microsurgical epiddiymal sperm aspiration. "a" and " $\mathrm{b}$ " were used to denote different patient cohorts examined within one study.

A recent meta-analysis examining sperm retrieval as well as pregnancy and LBRs was performed [3]. This review compared SRR after conventional TESE (CTESE) with that after microTESE, and found that the per procedure SRR was $45-49 \%$, and was not able to identify differences between conventional or microsurgical methods of sperm retrieval because the included studies did not include comparator trials [3]. Meta-regression analysis further demonstrated that SRR was independent of both age and hormonal parameters [3]. Testis volume greater than $12.5 \mathrm{~mL}$ was found to be associated with a greater than $60 \%$ chance of successful sperm retrieval with an accuracy of $86.2 \%$ [3]. The BCPR (diagnosed by positive serum hCG in the female partner) was $25-32 \%$ per ICSI cycle, and LBR was $20-28 \%$ [3]. It is important to note that the patient cohorts included in this meta-analysis were heterogenous with varying NOA etiologies, making the comparison of outcomes between cTESE and mTESE less valid. A previous meta-analysis which included fifteen comparative studies demonstrated a $17 \%$ higher likelihood of sperm retrieval success when performing mTESE compared to cTESE [2]. Additionally, it was noted that men who underwent mTESE had failed prior CTESE or TESA, which also may have underestimated the increase in sperm retrieval rate with mTESE [2]. Several, smaller studies have been performed examining NOA men based on underlying etiology, including KS, YCMD, malignancy, and cryptorchidism, and these will be discussed further.

\subsubsection{Klinefelter Syndrome}

A meta-analysis of 37 studies found a cumulative SRR of $44 \%$ (39-48\%) per TESE procedure in KS patients, with no significant difference between cTESE and mTESE [114]. ICSI outcomes were available for 29 of the 37 studies in the meta-analysis, and reported a cumulative CPR, defined by ultrasound detection of a gestational sac or heartbeat, of $43 \%$ (36-50\%), and LBR of $43 \%$ (34-53\%) per ICSI cycle [114]. SRR, CPR, and LBR in this analysis were independent of patient age at time of retrieval as well as testis volume, and serum hormone parameters [114]. Additionally, no differences between use of fresh versus frozen sperm were observed [114]. Again, it is important to note that this meta-analysis examined studies where the patient cohorts were not entirely made up of KS patients. In one of the largest published studies on SRR in KS patients, we report a SRR of $66 \%$ (Table 4) [61]. In our experience with KS patients, the appearance of tubules within the testis is unique amongst men with NOA. Instead of typically having sperm production throughout an individual seminiferous tubule, KS patients tend to have focal enlargement of otherwise sclerotic tubules within the testes. This appearance requires an intensive search within 
these typically very atrophic testes to find the millimeter-sized segments of tubules that may contain sperm. In addition, the number of sperm retrieved tends to be so small that sperm are typically not able to be frozen for later use. Therefore, the numbers of sperm obtained may be only adequate to inject available oocytes during a programmed, fresh in vitro fertilization (IVF) cycle.

Table 4. Sperm retrieval rates in non-obstructive azoospermia by etiology.

\begin{tabular}{ccc}
\hline NOA Etiology & $\begin{array}{c}\text { Weill Cornell Medicine } \\
\text { (P.N.S.) }\end{array}$ & Other Reports \\
\hline Idiopathic & $48.5 \%[46]$ & $37.4-65.8 \%[104,111]$ \\
Klinefelter syndrome & $61-66 \%[46,61]$ & $44 \%[114]$ \\
YCMD (AZFc) & $67-75 \%[17,46]$ & $20.4-54.8 \%[102,113,115]$ \\
Chemotherapy & $42 \%[46]$ & $37-60 \%[79,92,100]$ \\
Cryptorchidism & $62 \%[46]$ & $52-85 \%[41-45]$ \\
Overall & $48 \%[46]$ & $45-49 \%[3]$ \\
\hline
\end{tabular}

P.N.S., Peter N. Schlegel, attending urologist at Weill Cornell Medicine.

\subsubsection{Y-Chromosome Microdeletions}

Little is known regarding ICSI and clinical outcomes in NOA men with YCMD given that many of these studies excluded men with YCMD or included men with YCMD in a larger cohort of azoospermic men (Tables 3 and 4). SRRs differ drastically depending on the site of microdeletion. Sperm can be surgically retrieved in up to $70 \%$ of men with AZFc deletions and a subset may have low concentrations of sperm in the ejaculate, whereas no reports of sperm retrieval in men with complete $\mathrm{AZFa}$ or $\mathrm{AZFb}$ deletions have been effectively documented $[17,116]$. One study examining ICSI outcomes using ejaculated sperm demonstrated no significant difference in pregnancy, live birth, and miscarriage rates in men with $\mathrm{AZFC}$ microdeletions compared to those with other sources of infertility and no evidence of YCMD [117]. Another study found that men with AZFc microdeletions had a significantly increased fertilization rate when ejaculated sperm was used compared to testicular sperm [118]. With ejaculated sperm, pregnancy rate was $47 \%$ compared to $14 \%$ with testicular sperm [118]. Unfortunately, no predictors of successful sperm retrieval have been identified in this cohort, and it is important to inform couples that any male offspring will harbor the same Y-chromosome mutations [118,119].

\subsubsection{Chemotherapy-Associated NOA}

In men treated with chemotherapy, SRR ranges from 37 to $60 \%$, pregnancy rates 33-50\%, and LBR 22-42\% (Tables 3 and 4) [79,92,100]. Additional studies have been performed examining SRRs and ICSI outcomes, but men treated for malignancy (either with chemotherapy or radiation) are often pooled with men who have NOA due to other underlying etiologies. Therefore, the reported clinical outcomes may not be accurate for men with azoospermia solely secondary to chemotherapy or radiation treatment. One retrospective study of male cancer survivors found that following chemotherapy or radiation treatment, approximately 57\% were azoospermic [120]. This percentage is higher than expected in a full cohort of men treated with chemotherapy, as it reflects a referral bias to an infertility center for selected cancer survivors. The CPR was $38.6 \%$ and the LBR was 30.5\% after ICSI [120]. Overall, SRR and ICSI outcomes are generally favorable for men who have undergone treatment for malignancy. In testis cancer survivors, 3\% (who received chemotherapy) and 6\% (who received radiation therapy) remained azoospermic two years after therapy [121]. With increasingly aggressive chemotherapy treatment regimens, the rates of persistent azoospermia are higher [122]. However, fertility preservation prior to cancer treatment is still highly recommended as it is minimally invasive for men and can potentially portend less invasive treatments for the female partner [22]. 


\subsubsection{Cryptorchidism}

The mechanism underlying infertility in males with a history of cryptorchidism is not well understood. Men with bilateral cryptorchidism have a higher risk of infertility compared with those who have unilateral cryptorchidism $[38,39,123]$. Additionally, age at orchidopexy also affects sperm production and future fertility [40]. It is estimated that greater than $50 \%$ of men with a history of cryptorchidism will have varying degrees of spermatogenic failure and may require surgical sperm retrieval to conceive biological children $[39,123]$.

Men who have had prior orchidopexy typically have substantial peri-testicular scar, no tunica vaginalis, and often have an abnormal lie or position of the testis with an anterior epididymis. Surgical treatment in these men also often reveals an atypical blood supply to the testis with variable patterns of vessels on the tunica albuginea. Within the testis, most tubules are typically sclerotic with distinctively different tubules containing isolated foci of spermatogenesis visible during microdissection. Studies examining ICSI outcomes solely in men with a history of cryptorchidism report SRR ranging from 52 to $85 \%$, pregnancy rates ranging from $10-46 \%$, LBR ranging from $33-100 \%$, and miscarriage rates ranging from $6.3-8.1 \%$ (Tables 2 and 3) [41-45]. Patients with cryptorchidism have a wide range of fertility potential and more studies of these individuals is needed to determine the mechanisms underlying their infertility so that patients can be counseled with accurate prognostic information.

\subsection{Sperm Effects on ICSI Outcomes}

For men with severely impaired sperm production, embryo development appears to be adversely affected by the (testicular) source of sperm and level of sperm production with decreased development associated with higher FSH levels [124,125]. Men with NOA often have such low fertilization rates that a limited number of embryos exist on day 3 . Therefore, transfer of day 3 embryos is routinely required, as further in vitro culture risks losing the embryos available for transfer on day 3. Of note, high-quality day 3 embryos have been suggested in some studies to be equivalent to day 5 blastocysts in terms of pregnancy and live birth rate [124]. However, existing data are limited with no interpretable data on embryo morphokinetic parameters, although some publications suggest that embryo development may be less efficient in me with lower sperm production [124,126]. Similarly, there are limited published data on blastocyst euploidy rates. Given the frequency of day 3 embryo transfer for couples where men have NOA, data obtained from the select group with blastocysts available for transfer may not reflect results that are generalizable for NOA patients as a whole.

Advances in the understanding of sperm biology have revealed important paternal effects on embryo development and quality. Poor semen parameters have been demonstrated to negatively affect blastocyst formation rates after IVF and ICSI [124,126-129]. Ejaculated sperm has been found to produce higher fertilization and pregnancy rates than testicular sperm [130]. Additionally, when compared to men with obstructive azoospermia undergoing ICSI, men with NOA undergoing ICSI have lower rates of fertilization, blastocyst formation, implantation, and pregnancy [124,126,131,132].

\section{Improving ICSI Outcomes from the Male Perspective}

Optimization of hormone levels in NOA men may improve SRR [71]. Increased numbers of sperm may allow selection of more optimal sperm to be used for ICSI. Currently, various methods exist for improving sperm selection, including viability assays, cell sorting methods and enhanced microscopic analysis for selection of sperm for ICSI, although manual selection of individual sperm is the most common approach used in men with NOA [133].

Conventional sperm selection methods including the swim-up method, migration density, and density gradients rely heavily on the motility of sperm, and cannot be used for sperm retrieved from the testis as certain maturation processes have not occurred in 
testicular sperm and these sperm are immotile. Magnetic activated cell sorting (MACS) is a method of sperm selection using annexin V-conjugated magnetic beads to isolate viable sperm. A systematic review analyzing five prospective, randomized trials evaluating MACS compared to standard sperm selection methods (including swim-up and density gradient methods) found significantly increased pregnancy rates resulted after MACS [134]. Intracytoplasmic morphologically selected sperm injection (IMSI) is the process of selecting sperm at x6,600 magnification to examine motile sperm organellar morphology [133]. A prospective, randomized study examining ICSI and IMSI in couples with severe male factor infertility reported higher CPR with IMSI (39.2\% IMSI vs. 26.5\% ICSI, $p=0.004)$ [135]. This study along with other studies, including one meta-analysis, also demonstrated a decreased miscarriage rate and improved implantation rates with IMSI compared with ICSI $[133,135]$. However, a recent Cochrane review of the efficacy of IMSI compared with traditional ICSI did not provide any conclusive evidence to suggest that IMSI is superior to ICSI in terms of clinical outcomes (CPR, LBR) [136].

Additional work on novel techniques is underway that will further optimize the sperm chosen for oocyte injection. One promising technique is microfluidic sorting of sperm, which allows for analysis of sperm count, motility, and morphology on a microscopic level, allowing for the identification and selection of sperm with the best qualities [137,138]. Studies examining microfluidics-sorted sperm have demonstrated improved ICSI and clinical outcomes compared to sperm selected by conventional methods [138,139]. However, further work is needed to fully develop this technology for mainstream use [140]. Given the limited numbers of sperm available for retrieval from men with NOA, it is more challenging to apply sperm selection techniques that could be used for sperm samples from men with oligozoospermia.

\section{Conclusions}

ICSI has permitted NOA men, who were previously unable, to conceive biological children. Studies have demonstrated varying rates of clinical (pregnancy and live birth rates) outcomes likely due to a heterogenous population of men with NOA included in these studies, and future studies would benefit from etiology-specific outcome reporting. Understanding clinical outcomes after ICSI is important for prognostic information and counseling of these NOA men and their partners prior to undergoing invasive surgical procedures. Further work is needed to delineate the molecular mechanisms and genetic defects that underlie this severe reproductive phenotype.

Author Contributions: Conceptualization P.N.S.; writing-C.K., N.P., and P.N.S.; review and editingC.K., N.P., and P.N.S.; supervision P.N.S. All authors have read and agreed to the published version of the manuscript.

Funding: C.K. and N.P. are supported in part by the Frederick J. and Theresa Dow Wallace Fund of the New York Community Trust.

Data Availability Statement: Not applicable.

Conflicts of Interest: The authors have no conflict of interest to declare.

\section{References}

1. Leifke, E.; Nieschlag, E. Male infertility treatment in the light of evidence-based medicine. Andrologia 1996, 28, 23-30. [PubMed]

2. Bernie, A.M.; Mata, D.A.; Ramasamy, R.; Schlegel, P.N. Comparison of microdissection testicular sperm extraction, conventional testicular sperm extraction, and testicular sperm aspiration for nonobstructive azoospermia: A systematic review and metaanalysis. Fertil. Steril. 2015, 104, 1099-1103.e3. [CrossRef] [PubMed]

3. Corona, G.; Minhas, S.; Giwercman, A.; Bettocchi, C.; Dinkelman-Smit, M.; Dohle, G.; Fusco, F.; Kadioglou, A.; Kliesch, S.; Kopa, Z.; et al. Sperm recovery and ICSI outcomes in men with non-obstructive azoospermia: A systematic review and meta-analysis. Hum. Reprod. Update 2019, 25, 733-757. [CrossRef]

4. Schlegel, P.N. Testicular sperm extraction: Microdissection improves sperm yield with minimal tissue excision. Hum. Reprod. 1999, 14, 131-135. [CrossRef] [PubMed]

5. Esteves, S.C. Clinical management of infertile men with nonobstructive azoospermia. Asian J. Androl. 2015, 17, 459-470. [CrossRef] 
6. Kumar, R. Medical management of non-obstructive azoospermia. Clinics 2013, 68, 75-79. [CrossRef]

7. Romijn, J.A. Hyperprolactinemia and prolactinoma. Handb. Clin. Neurol. 2014, 124, 185-195. [CrossRef]

8. Merino, G.; Carranza-Lira, S.; Martinez-Chéquer, J.C.; Barahona, E.; Morán, C.; Bermúdez, J.A. Hyperprolactinemia in men with asthenozoospermia, oligozoospermia, or azoospermia. Arch. Androl. 1997, 38, 201-206. [CrossRef]

9. Stahl, P.J.; Schlegel, P.N. Genetic evaluation of the azoospermic or severely oligozoospermic male. Curr. Opin. Obstet. Gynecol. 2012, 24, 221-228. [CrossRef]

10. Suganya, J.; Kujur, S.B.; Selvaraj, K.; Suruli, M.S.; Haripriya, G.; Samuel, C.R. Chromosomal Abnormalities in Infertile Men from Southern India. J. Clin. Diagn. Res. 2015, 9, GC05-10. [CrossRef]

11. Abramsky, L.; Chapple, J. 47,XXY (Klinefelter syndrome) and 47,XYY: Estimated rates of and indication for postnatal diagnosis with implications for prenatal counselling. Prenat. Diagn. 1997, 17, 363-368. [CrossRef]

12. Maduro, M.R.; Lamb, D.J. Understanding new genetics of male infertility. J. Urol. 2002, 168, 2197-2205. [CrossRef]

13. Bonomi, M.; Rochira, V.; Pasquali, D.; Balercia, G.; Jannini, E.A.; Ferlin, A.; Klinefelter Italia, N.G. Klinefelter syndrome (KS): Genetics, clinical phenotype and hypogonadism. J. Endocrinol. Investig. 2017, 40, 123-134. [CrossRef] [PubMed]

14. Lanfranco, F.; Kamischke, A.; Zitzmann, M.; Nieschlag, E. Klinefelter's syndrome. Lancet 2004, 364, 273-283. [CrossRef]

15. Aksglaede, L.; Wikstrom, A.M.; Rajpert-De Meyts, E.; Dunkel, L.; Skakkebaek, N.E.; Juul, A. Natural history of seminiferous tubule degeneration in Klinefelter syndrome. Hum. Reprod. Update 2006, 12, 39-48. [CrossRef]

16. Fainberg, J.; Hayden, R.P.; Schlegel, P.N. Fertility management of Klinefelter syndrome. Expert Rev. Endocrinol. Metab 2019, 14, 369-380. [CrossRef]

17. Hopps, C.V.; Mielnik, A.; Goldstein, M.; Palermo, G.D.; Rosenwaks, Z.; Schlegel, P.N. Detection of sperm in men with Y chromosome microdeletions of the AZFa, AZFb and AZFc regions. Hum. Reprod. 2003, 18, 1660-1665. [CrossRef]

18. Vogt, P.H.; Edelmann, A.; Kirsch, S.; Henegariu, O.; Hirschmann, P.; Kiesewetter, F.; Kohn, F.M.; Schill, W.B.; Farah, S.; Ramos, C.; et al. Human Y chromosome azoospermia factors (AZF) mapped to different subregions in Yq11. Hum. Mol. Genet. 1996, 5, 933-943. [CrossRef]

19. Vogt, P.H. AZF deletions and Y chromosomal haplogroups: History and update based on sequence. Hum. Reprod. Update 2005, 11, 319-336. [CrossRef]

20. Colaco, S.; Modi, D. Genetics of the human Y chromosome and its association with male infertility. Reprod. Biol. Endocrinol. 2018, 16, 14. [CrossRef]

21. Bansal, S.K.; Jaiswal, D.; Gupta, N.; Singh, K.; Dada, R.; Sankhwar, S.N.; Gupta, G.; Rajender, S. Gr/gr deletions on Y-chromosome correlate with male infertility: An original study, meta-analyses, and trial sequential analyses. Sci. Rep. 2016, 6, 19798. [CrossRef] [PubMed]

22. Schlegel, P.N.; Sigman, M.; Collura, B.; De Jonge, C.J.; Eisenberg, M.L.; Lamb, D.J.; Mulhall, J.P.; Niederberger, C.; Sandlow, J.I.; Sokol, R.Z.; et al. Diagnosis and Treatment of Infertility in Men: AUA/ASRM Guideline Part I. J. Urol. 2021, 205, 36-43. [CrossRef] [PubMed]

23. Georgiou, I.; Syrrou, M.; Pardalidis, N.; Karakitsios, K.; Mantzavinos, T.; Giotitsas, N.; Loutradis, D.; Dimitriadis, F.; Saito, M.; Miyagawa, I.; et al. Genetic and epigenetic risks of intracytoplasmic sperm injection method. Asian J. Androl. 2006, 8, 643-673. [CrossRef]

24. Osterberg, E.C.; Ramasamy, R.; Masson, P.; Brannigan, R.E. Current practices in fertility preservation in male cancer patients. Urol. Ann. 2014, 6, 13-17. [CrossRef] [PubMed]

25. Howell, S.J.; Radford, J.A.; Ryder, W.D.; Shalet, S.M. Testicular function after cytotoxic chemotherapy: Evidence of Leydig cell insufficiency. J. Clin. Oncol. 1999, 17, 1493-1498. [CrossRef] [PubMed]

26. Meistrich, M.L. Effects of chemotherapy and radiotherapy on spermatogenesis in humans. Fertil. Steril. 2013, 100, 1180-1186. [CrossRef] [PubMed]

27. Dasari, S.; Tchounwou, P.B. Cisplatin in cancer therapy: Molecular mechanisms of action. Eur. J. Pharmacol 2014, 740, 364-378. [CrossRef] [PubMed]

28. Green, D.M.; Nolan, V.G.; Goodman, P.J.; Whitton, J.A.; Srivastava, D.; Leisenring, W.M.; Neglia, J.P.; Sklar, C.A.; Kaste, S.C.; Hudson, M.M.; et al. The cyclophosphamide equivalent dose as an approach for quantifying alkylating agent exposure: A report from the Childhood Cancer Survivor Study. Pediatr. Blood Cancer 2014, 61, 53-67. [CrossRef]

29. Green, D.M.; Liu, W.; Kutteh, W.H.; Ke, R.W.; Shelton, K.C.; Sklar, C.A.; Chemaitilly, W.; Pui, C.H.; Klosky, J.L.; Spunt, S.L.; et al. Cumulative alkylating agent exposure and semen parameters in adult survivors of childhood cancer: A report from the St Jude Lifetime Cohort Study. Lancet Oncol. 2014, 15, 1215-1223. [CrossRef]

30. Okada, K.; Fujisawa, M. Recovery of Spermatogenesis Following Cancer Treatment with Cytotoxic Chemotherapy and Radiotherapy. World J. Mens Health 2019, 37, 166-174. [CrossRef]

31. Dohle, G.R. Male infertility in cancer patients: Review of the literature. Int. J. Urol. 2010, 17, 327-331. [CrossRef] [PubMed]

32. Loren, A.W.; Mangu, P.B.; Beck, L.N.; Brennan, L.; Magdalinski, A.J.; Partridge, A.H.; Quinn, G.; Wallace, W.H.; Oktay, K.; American Society of Clinical, O. Fertility preservation for patients with cancer: American Society of Clinical Oncology clinical practice guideline update. J. Clin. Oncol. 2013, 31, 2500-2510. [CrossRef] [PubMed]

33. Ethics Committee of the American Society for Reproductive Medicine. Fertility preservation and reproduction in patients facing gonadotoxic therapies: An Ethics Committee opinion. Fertil. Steril. 2018, 110, 380-386. [CrossRef] [PubMed] 
34. Schlegel, P.N.; Sigman, M.; Collura, B.; De Jonge, C.J.; Eisenberg, M.L.; Lamb, D.J.; Mulhall, J.P.; Niederberger, C.; Sandlow, J.I.; Sokol, R.Z.; et al. Diagnosis and Treatment of Infertility in Men: AUA/ASRM Guideline PART II. J. Urol. 2021, $205,44-51$. [CrossRef] [PubMed]

35. Meistrich, M.L. Risks of genetic damage in offspring conceived using spermatozoa produced during chemotherapy or radiotherapy. Andrology 2020, 8, 545-558. [CrossRef] [PubMed]

36. Gurney, J.K.; McGlynn, K.A.; Stanley, J.; Merriman, T.; Signal, V.; Shaw, C.; Edwards, R.; Richiardi, L.; Hutson, J.; Sarfati, D. Risk factors for cryptorchidism. Nat. Rev. Urol. 2017, 14, 534-548. [CrossRef]

37. Cortes, D. Cryptorchidism-aspects of pathogenesis, histology and treatment. Scand. J. Urol. Nephrol. Suppl. 1998, 196, 1-54. [PubMed]

38. Hanson, B.M.; Eisenberg, M.L.; Hotaling, J.M. Male infertility: A biomarker of individual and familial cancer risk. Fertil. Steril. 2018, 109, 6-19. [CrossRef]

39. Cobellis, G.; Noviello, C.; Nino, F.; Romano, M.; Mariscoli, F.; Martino, A.; Parmeggiani, P.; Papparella, A. Spermatogenesis and cryptorchidism. Front. Endocrinol. 2014, 5, 63. [CrossRef]

40. Rodprasert, W.; Virtanen, H.E.; Mäkelä, J.A.; Toppari, J. Hypogonadism and Cryptorchidism. Front. Endocrinol. 2019, 10, 906. [CrossRef] [PubMed]

41. Chen, X.; Ma, Y.; Zou, S.; Wang, S.; Qiu, J.; Xiao, Q.; Zhou, L.; Ping, P. Comparison and outcomes of nonobstructive azoospermia patients with different etiology undergoing MicroTESE and ICSI treatments. Transl. Androl. Urol. 2019, 8, 366-373. [CrossRef] [PubMed]

42. Raman, J.D.; Schlegel, P.N. Testicular sperm extraction with intracytoplasmic sperm injection is successful for the treatment of nonobstructive azoospermia associated with cryptorchidism. J. Urol. 2003, 170, 1287-1290. [CrossRef] [PubMed]

43. Vernaeve, V.; Krikilion, A.; Verheyen, G.; Van Steirteghem, A.; Devroey, P.; Tournaye, H. Outcome of testicular sperm recovery and ICSI in patients with non-obstructive azoospermia with a history of orchidopexy. Hum. Reprod. 2004, 19, 2307-2312. [CrossRef] [PubMed]

44. Wiser, A.; Raviv, G.; Weissenberg, R.; Elizur, S.E.; Levron, J.; Machtinger, R.; Madgar, I. Does age at orchidopexy impact on the results of testicular sperm extraction? Reprod. Biomed. Online 2009, 19, 778-783. [CrossRef]

45. Tsai, Y.R.; Huang, F.J.; Lin, P.Y.; Kung, F.T.; Lin, Y.J.; Lan, K.C. Clinical outcomes and development of children born to couples with obstructive and nonobstructive azoospermia undergoing testicular sperm extraction-intracytoplasmic sperm injection: A comparative study. Taiwan J. Obstet. Gynecol. 2015, 54, 155-159. [CrossRef] [PubMed]

46. Dabaja, A.A.; Schlegel, P.N. Microdissection testicular sperm extraction: An update. Asian J. Androl. 2013, 15, 35-39. [CrossRef]

47. Gorelick, J.I.; Goldstein, M. Loss of fertility in men with varicocele. Fertil. Steril. 1993, 59, 613-616. [CrossRef]

48. Esteves, S.C.; Glina, S. Recovery of spermatogenesis after microsurgical subinguinal varicocele repair in azoospermic men based on testicular histology. Int. Braz. J. Urol. 2005, 31, 541-548. [CrossRef]

49. Sedaghatpour, D.; Berookhim, B.M. The Role of Varicocele in Male Factor Subfertility. Curr. Urol. Rep. 2017, 18, 73. [CrossRef]

50. Hassanin, A.M.; Ahmed, H.H.; Kaddah, A.N. A global view of the pathophysiology of varicocele. Andrology 2018, 6, 654-661. [CrossRef]

51. Shiraishi, K.; Naito, K. Effects of 4-hydroxy-2-nonenal, a marker of oxidative stress, on spermatogenesis and expression of p53 protein in male infertility. J. Urol. 2007, 178, 1012-1017, discussion 1017. [CrossRef] [PubMed]

52. Ogi, S.; Tanji, N.; Iseda, T.; Yokoyama, M. Expression of heat shock proteins in developing and degenerating rat testes. Arch. Androl. 1999, 43, 163-171. [CrossRef] [PubMed]

53. Tanrikut, C.; Goldstein, M.; Rosoff, J.S.; Lee, R.K.; Nelson, C.J.; Mulhall, J.P. Varicocele as a risk factor for androgen deficiency and effect of repair. BJU Int. 2011, 108, 1480-1484. [CrossRef] [PubMed]

54. Schlegel, P.N.; Kaufmann, J. Role of varicocelectomy in men with nonobstructive azoospermia. Fertil. Steril. 2004, 81, 1585-1588. [CrossRef] [PubMed]

55. Samplaski, M.K.; Nangia, A.K. Adverse effects of common medications on male fertility. Nat. Rev. Urol. 2015, 12, 401-413. [CrossRef]

56. Reifsnyder, J.E.; Ramasamy, R.; Husseini, J.; Schlegel, P.N. Role of optimizing testosterone before microdissection testicular sperm extraction in men with nonobstructive azoospermia. J. Urol. 2012, 188, 532-536. [CrossRef] [PubMed]

57. Schlegel, P.N. Aromatase inhibitors for male infertility. Fertil. Steril. 2012, 98, 1359-1362. [CrossRef]

58. Pavlovich, C.P.; King, P.; Goldstein, M.; Schlegel, P.N. Evidence of a treatable endocrinopathy in infertile men. J. Urol. 2001, 165, 837-841. [CrossRef]

59. Raman, J.D.; Schlegel, P.N. Aromatase inhibitors for male infertility. J. Urol. 2002, 167, 624-629. [CrossRef]

60. Ramasamy, R.; Stahl, P.J.; Schlegel, P.N. Medical therapy for spermatogenic failure. Asian J. Androl. 2012, 14, 57-60. [CrossRef]

61. Ramasamy, R.; Ricci, J.A.; Palermo, G.D.; Gosden, L.V.; Rosenwaks, Z.; Schlegel, P.N. Successful fertility treatment for Klinefelter's syndrome. J. Urol. 2009, 182, 1108-1113. [CrossRef] [PubMed]

62. Schiff, J.D.; Palermo, G.D.; Veeck, L.L.; Goldstein, M.; Rosenwaks, Z.; Schlegel, P.N. Success of testicular sperm extraction [corrected] and intracytoplasmic sperm injection in men with Klinefelter syndrome. J. Clin. Endocrinol. Metab. 2005, 90, 6263-6267. [CrossRef] [PubMed]

63. Moradi, M.; Moradi, A.; Alemi, M.; Ahmadnia, H.; Abdi, H.; Ahmadi, A.; Bazargan-Hejazi, S. Safety and efficacy of clomiphene citrate and L-carnitine in idiopathic male infertility: A comparative study. Urol. J. 2010, 7, 188-193. [PubMed] 
64. Roth, L.W.; Ryan, A.R.; Meacham, R.B. Clomiphene citrate in the management of male infertility. Semin. Reprod. Med. 2013, 31, 245-250. [CrossRef] [PubMed]

65. Palermo, G.; Joris, H.; Devroey, P.; Van Steirteghem, A.C. Pregnancies after intracytoplasmic injection of single spermatozoon into an oocyte. Lancet 1992, 340, 17-18. [CrossRef]

66. Devroey, P.; Liu, J.; Nagy, Z.; Goossens, A.; Tournaye, H.; Camus, M.; Van Steirteghem, A.; Silber, S. Pregnancies after testicular sperm extraction and intracytoplasmic sperm injection in non-obstructive azoospermia. Hum. Reprod. 1995, 10, 1457-1460. [CrossRef]

67. Bernie, A.M.; Ramasamy, R.; Stember, D.S.; Stahl, P.J. Microsurgical epididymal sperm aspiration: Indications, techniques and outcomes. Asian J. Androl. 2013, 15, 40-43. [CrossRef]

68. Kavoussi, P.K.; West, B.T.; Chen, S.H.; Hunn, C.; Gilkey, M.S.; Machen, G.L.; Kavoussi, K.M.; Esqueda, A.; Wininger, J.D.; Kavoussi, S.K. A comprehensive assessment of predictors of fertility outcomes in men with non-obstructive azoospermia undergoing microdissection testicular sperm extraction. Reprod. Biol. Endocrinol. 2020, 18, 90. [CrossRef]

69. Pavan-Jukic, D.; Stubljar, D.; Jukic, T.; Starc, A. Predictive factors for sperm retrieval from males with azoospermia who are eligible for testicular sperm extraction (TESE). Syst. Biol. Reprod. Med. 2020, 66, 70-75. [CrossRef]

70. Dohle, G.R.; Elzanaty, S.; van Casteren, N.J. Testicular biopsy: Clinical practice and interpretation. Asian J. Androl. 2012, 14, 88-93. [CrossRef]

71. Guler, I.; Erdem, M.; Erdem, A.; Demirdă̆, E.; Tunc, L.; Bozkurt, N.; Mutlu, M.F.; Oktem, M. Impact of testicular histopathology as a predictor of sperm retrieval and pregnancy outcome in patients with nonobstructive azoospermia: Correlation with clinical and hormonal factors. Andrologia 2016, 48, 765-773. [CrossRef]

72. Cavallini, G.; Cristina Magli, M.; Crippa, A.; Resta, S.; Vitali, G.; Pia Ferraretti, A.; Gianaroli, L. The number of spermatozoa collected with testicular sperm extraction is a novel predictor of intracytoplasmic sperm injection outcome in non-obstructive azoospermic patients. Asian J. Androl. 2011, 13, 312-316. [CrossRef]

73. Boulet, S.L.; Mehta, A.; Kissin, D.M.; Warner, L.; Kawwass, J.F.; Jamieson, D.J. Trends in use of and reproductive outcomes associated with intracytoplasmic sperm injection. Jama 2015, 313, 255-263. [CrossRef] [PubMed]

74. Fahmy, I.; Mansour, R.; Aboulghar, M.; Serour, G.; Kamal, A.; Tawab, N.A.; Ramzy, A.M.; Amin, Y. Intracytoplasmic sperm injection using surgically retrieved epididymal and testicular spermatozoa in cases of obstructive and non-obstructive azoospermia. Int. J. Androl. 1997, 20, 37-44. [CrossRef] [PubMed]

75. Friedler, S.; Raziel, A.; Strassburger, D.; Soffer, Y.; Komarovsky, D.; Ron-El, R. Testicular sperm retrieval by percutaneous fine needle sperm aspiration compared with testicular sperm extraction by open biopsy in men with non-obstructive azoospermia. Hum. Reprod. 1997, 12, 1488-1493. [CrossRef] [PubMed]

76. Ben-Yosef, D.; Yogev, L.; Hauser, R.; Yavetz, H.; Azem, F.; Yovel, I.; Lessing, J.B.; Amit, A. Testicular sperm retrieval and cryopreservation prior to initiating ovarian stimulation as the first line approach in patients with non-obstructive azoospermia. Hum. Reprod. 1999, 14, 1794-1801. [CrossRef]

77. Palermo, G.D.; Schlegel, P.N.; Hariprashad, J.J.; Ergün, B.; Mielnik, A.; Zaninovic, N.; Veeck, L.L.; Rosenwaks, Z. Fertilization and pregnancy outcome with intracytoplasmic sperm injection for azoospermic men. Hum. Reprod. 1999, 14, 741-748. [CrossRef]

78. Mercan, R.; Urman, B.; Alatas, C.; Aksoy, S.; Nuhoglu, A.; Isiklar, A.; Balaban, B. Outcome of testicular sperm retrieval procedures in non-obstructive azoospermia: Percutaneous aspiration versus open biopsy. Hum. Reprod. 2000, 15, 1548-1551. [CrossRef]

79. Chan, P.T.; Palermo, G.D.; Veeck, L.L.; Rosenwaks, Z.; Schlegel, P.N. Testicular sperm extraction combined with intracytoplasmic sperm injection in the treatment of men with persistent azoospermia postchemotherapy. Cancer 2001, 92, 1632-1637. [CrossRef]

80. Damani, M.N.; Master, V.; Meng, M.V.; Burgess, C.; Turek, P.; Oates, R.D. Postchemotherapy ejaculatory azoospermia: Fatherhood with sperm from testis tissue with intracytoplasmic sperm injection. J. Clin. Oncol. 2002, 20, 930-936. [CrossRef]

81. Friedler, S.; Raziel, A.; Schachter, M.; Strassburger, D.; Bern, O.; Ron-El, R. Outcome of first and repeated testicular sperm extraction and ICSI in patients with non-obstructive azoospermia. Hum. Reprod. 2002, 17, 2356-2361. [CrossRef] [PubMed]

82. Mátyás, S.; Rajczy, K.; Papp, G.; Bernard, A.; Korponai, E.; Kovács, T.; Krizsa, F.; Kulin, S.; Menyhárt, R.; Szmatona, G.; et al. Five years experiences with microinjection of testicular spermatozoa into oocytes in Hungary. Andrologia 2002, 34, 248-254. [CrossRef] [PubMed]

83. Bailly, M.; Guthauser, B.; Bergere, M.; Wainer, R.; Lombroso, R.; Ville, Y.; Selva, J. Effects of low concentrations of inhibin B on the outcomes of testicular sperm extraction and intracytoplasmic sperm injection. Fertil. Steril. 2003, 79, 905-908. [CrossRef]

84. Mansour, R.T.; Fahmy, I.M.; Taha, A.K.; Tawab, N.A.; Serour, G.I.; Aboulghar, M.A. Intracytoplasmic spermatid injection can result in the delivery of normal offspring. J. Androl. 2003, 24, 757-764. [CrossRef] [PubMed]

85. Meseguer, M.; Garrido, N.; Remohí, J.; Pellicer, A.; Simón, C.; Martínez-Jabaloyas, J.M.; Gil-Salom, M. Testicular sperm extraction (TESE) and ICSI in patients with permanent azoospermia after chemotherapy. Hum. Reprod. 2003, 18, 1281-1285. [CrossRef] [PubMed]

86. Osmanagaoglu, K.; Vernaeve, V.; Kolibianakis, E.; Tournaye, H.; Camus, M.; Van Steirteghem, A.; Devroey, P. Cumulative delivery rates after ICSI treatment cycles with freshly retrieved testicular sperm: A 7-year follow-up study. Hum. Reprod. 2003, 18, 1836-1840. [CrossRef] [PubMed]

87. Aydos, K.; Demirel, L.C.; Baltaci, V.; Unlü, C. Enzymatic digestion plus mechanical searching improves testicular sperm retrieval in non-obstructive azoospermia cases. Eur. J. Obstet. Gynecol. Reprod. Biol. 2005, 120, 80-86. [CrossRef] 
88. Giorgetti, C.; Chinchole, J.M.; Hans, E.; Charles, O.; Franquebalme, J.P.; Glowaczower, E.; Salzmann, J.; Terriou, P.; Roulier, R. Crude cumulative delivery rate following ICSI using intentionally frozen-thawed testicular spermatozoa in 51 men with non-obstructive azoospermia. Reprod. Biomed. Online 2005, 11, 319-324. [CrossRef]

89. Mitchell, V.; Steger, K.; Marchetti, C.; Herbaut, J.C.; Devos, P.; Rigot, J.M. Cellular expression of protamine 1 and 2 transcripts in testicular spermatids from azoospermic men submitted to TESE-ICSI. Mol. Hum. Reprod. 2005, 11, 373-379. [CrossRef]

90. Wu, B.; Wong, D.; Lu, S.; Dickstein, S.; Silva, M.; Gelety, T.J. Optimal use of fresh and frozen-thawed testicular sperm for intracytoplasmic sperm injection in azoospermic patients. J. Assist. Reprod. Genet. 2005, 22, 389-394. [CrossRef]

91. Everaert, K.; De Croo, I.; Kerckhaert, W.; Dekuyper, P.; Dhont, M.; Van der Elst, J.; De Sutter, P.; Comhaire, F.; Mahmoud, A.; Lumen, N. Long term effects of micro-surgical testicular sperm extraction on androgen status in patients with non obstructive azoospermia. BMC Urol. 2006, 6, 9. [CrossRef]

92. Hibi, H.; Ohori, T.; Yamada, Y.; Honda, N.; Hashiba, Y.; Asada, Y. Testicular sperm extraction and ICSI in patients with post-chemotherapy non-obstructive azoospermia. Arch. Androl. 2007, 53, 63-65. [CrossRef]

93. Mitchell, V.; Lefebvre-Khalil, V.; Thomas, P.; Rigot, J.M.; Steger, K. Transition protein 1 mRNA expression is not related to pregnancy rate in azoospermic men undergoing TESE-ICSI. Andrologia 2007, 39, 124-127. [CrossRef] [PubMed]

94. Kanto, S.; Sugawara, J.; Masuda, H.; Sasano, H.; Arai, Y.; Kyono, K. Fresh motile testicular sperm retrieved from nonobstructive azoospermic patients has the same potential to achieve fertilization and pregnancy via ICSI as sperm retrieved from obstructive azoospermic patients. Fertil. Steril. 2008, 90, 2010.e5-2010.e7. [CrossRef] [PubMed]

95. Ravizzini, P.; Carizza, C.; Abdelmassih, V.; Abdelmassih, S.; Azevedo, M.; Abdelmassih, R. Microdissection testicular sperm extraction and IVF-ICSI outcome in nonobstructive azoospermia. Andrologia 2008, 40, 219-226. [CrossRef]

96. Ishikawa, T.; Shiotani, M.; Izumi, Y.; Hashimoto, H.; Kokeguchi, S.; Goto, S.; Fujisawa, M. Fertilization and pregnancy using cryopreserved testicular sperm for intracytoplasmic sperm injection with azoospermia. Fertil. Steril. 2009, 92, 174-179. [CrossRef]

97. Yarali, H.; Polat, M.; Bozdag, G.; Gunel, M.; Alpas, I.; Esinler, I.; Dogan, U.; Tiras, B. TESE-ICSI in patients with non-mosaic Klinefelter syndrome: A comparative study. Reprod. Biomed. Online 2009, 18, 756-760. [CrossRef]

98. Boitrelle, F.; Robin, G.; Marcelli, F.; Albert, M.; Leroy-Martin, B.; Dewailly, D.; Rigot, J.M.; Mitchell, V. A predictive score for testicular sperm extraction quality and surgical ICSI outcome in non-obstructive azoospermia: A retrospective study. Hum. Reprod. 2011, 26, 3215-3221. [CrossRef]

99. Hauser, R.; Bibi, G.; Yogev, L.; Carmon, A.; Azem, F.; Botchan, A.; Yavetz, H.; Klieman, S.E.; Lehavi, O.; Amit, A.; et al. Virtual azoospermia and cryptozoospermia-fresh/frozen testicular or ejaculate sperm for better IVF outcome? J. Androl. 2011, 32, 484-490. [CrossRef]

100. Hsiao, W.; Stahl, P.J.; Osterberg, E.C.; Nejat, E.; Palermo, G.D.; Rosenwaks, Z.; Schlegel, P.N. Successful treatment of postchemotherapy azoospermia with microsurgical testicular sperm extraction: The Weill Cornell experience. J. Clin. Oncol. 2011, 29, 1607-1611. [CrossRef]

101. Ashraf, M.C.; Singh, S.; Raj, D.; Ramakrishnan, S.; Esteves, S.C. Micro-dissection testicular sperm extraction as an alternative for sperm acquisition in the most difficult cases of Azoospermia: Technique and preliminary results in India. J. Hum. Reprod. Sci. 2013, 6, 111-123. [CrossRef] [PubMed]

102. Choi, D.K.; Gong, I.H.; Hwang, J.H.; Oh, J.J.; Hong, J.Y. Detection of Y Chromosome Microdeletion is Valuable in the Treatment of Patients With Nonobstructive Azoospermia and Oligoasthenoteratozoospermia: Sperm Retrieval Rate and Birth Rate. Korean J. Urol. 2013, 54, 111-116. [CrossRef]

103. Karacan, M.; Alwaeely, F.; Erkan, S.; Çebi, Z.; Berberoğlugil, M.; Batukan, M.; Uluğ, M.; Arvas, A.; Çamlıbel, T. Outcome of intracytoplasmic sperm injection cycles with fresh testicular spermatozoa obtained on the day of or the day before oocyte collection and with cryopreserved testicular sperm in patients with azoospermia. Fertil. Steril. 2013, 100, 975-980. [CrossRef] [PubMed]

104. Arafa, M.M.; ElBardisi, H.T.; AlSaid, S.S.; Majzoub, A.; AlMalki, A.H.; ElRobi, I.; AlAnsari, A.A. Outcome of microsurgical testicular sperm extraction in familial idiopathic nonobstructive azoospermia. Andrologia 2015, 47, 1062-1067. [CrossRef] [PubMed]

105. Esteves, S.C.; Prudencio, C.; Seol, B.; Verza, S.; Knoedler, C.; Agarwal, A. Comparison of sperm retrieval and reproductive outcome in azoospermic men with testicular failure and obstructive azoospermia treated for infertility. Asian J. Androl. 2014, 16, 602-606. [CrossRef]

106. Karacan, M.; Ulug, M.; Arvas, A.; Cebi, Z.; Erkan, S.; Camlıbel, T. Live birth rate with repeat microdissection TESE and intracytoplasmic sperm injection after a conventional testicular biopsy in men with nonobstructive azoospermia. Eur. J. Obstet. Gynecol. Reprod. Biol. 2014, 183, 174-177. [CrossRef] [PubMed]

107. Aydin, T.; Sofikerim, M.; Yucel, B.; Karadag, M.; Tokat, F. Effects of testicular histopathology on sperm retrieval rates and ICSI results in non-obstructive azoospermia. J. Obstet. Gynaecol. 2015, 35, 829-831. [CrossRef] [PubMed]

108. Vloeberghs, V.; Verheyen, G.; Haentjens, P.; Goossens, A.; Polyzos, N.P.; Tournaye, H. How successful is TESE-ICSI in couples with non-obstructive azoospermia? Hum. Reprod. 2015, 30, 1790-1796. [CrossRef] [PubMed]

109. Ko, J.K.; Chai, J.; Lee, V.C.; Li, R.H.; Lau, E.; Ho, K.L.; Tam, P.C.; Yeung, W.S.; Ho, P.C.; Ng, E.H. Sperm retrieval rate and pregnancy rate in infertile couples undergoing in-vitro fertilisation and testicular sperm extraction for non-obstructive azoospermia in Hong Kong. Hong Kong Med. J. 2016, 22, 556-562. [CrossRef] [PubMed] 
110. Alfano, M.; Ventimiglia, E.; Locatelli, I.; Capogrosso, P.; Cazzaniga, W.; Pederzoli, F.; Frego, N.; Matloob, R.; Saccà, A.; Pagliardini, L.; et al. Anti-Mullerian Hormone-to-Testosterone Ratio is Predictive of Positive Sperm Retrieval in Men with Idiopathic Non-Obstructive Azoospermia. Sci. Rep. 2017, 7, 17638. [CrossRef]

111. Arafa, M.M.; Majzoub, A.; AlSaid, S.S.; El Ansari, W.; Al Ansari, A.; Elbardisi, Y.; Elbardisi, H.T. Chromosomal abnormalities in infertile men with azoospermia and severe oligozoospermia in Qatar and their association with sperm retrieval intracytoplasmic sperm injection outcomes. Arab. J. Urol. 2018, 16, 132-139. [CrossRef] [PubMed]

112. Yu, Y.; Xi, Q.; Pan, Y.; Jiang, Y.; Zhang, H.; Li, L.; Liu, R. Pregnancy and Neonatal Outcomes in Azoospermic Men After Intracytoplasmic Sperm Injection Using Testicular Sperm and Donor Sperm. Med. Sci. Monit 2018, 24, 6968-6974. [CrossRef] [PubMed]

113. Yamaguchi, K.; Ishikawa, T.; Mizuta, S.; Takeuchi, T.; Matsubayashi, H.; Kokeguchi, S.; Habara, T.; Ichioka, K.; Ohashi, M.; Okamoto, S.; et al. Clinical outcomes of microdissection testicular sperm extraction and intracytoplasmic sperm injection in Japanese men with Y chromosome microdeletions. Reprod. Med. Biol. 2020, 19, 158-163. [CrossRef] [PubMed]

114. Corona, G.; Pizzocaro, A.; Lanfranco, F.; Garolla, A.; Pelliccione, F.; Vignozzi, L.; Ferlin, A.; Foresta, C.; Jannini, E.A.; Maggi, M.; et al. Sperm recovery and ICSI outcomes in Klinefelter syndrome: A systematic review and meta-analysis. Hum. Reprod. Update 2017, 23, 265-275. [CrossRef]

115. Park, S.H.; Lee, H.S.; Choe, J.H.; Lee, J.S.; Seo, J.T. Success rate of microsurgical multiple testicular sperm extraction and sperm presence in the ejaculate in korean men with y chromosome microdeletions. Korean J. Urol. 2013, 54, 536-540. [CrossRef] [PubMed]

116. Stahl, P.J.; Masson, P.; Mielnik, A.; Marean, M.B.; Schlegel, P.N.; Paduch, D.A. A decade of experience emphasizes that testing for Y microdeletions is essential in American men with azoospermia and severe oligozoospermia. Fertil. Steril. 2010, 94, 1753-1756. [CrossRef]

117. Liu, X.H.; Qiao, J.; Li, R.; Yan, L.Y.; Chen, L.X. Y chromosome AZFc microdeletion may not affect the outcomes of ICSI for infertile males with fresh ejaculated sperm. J. Assist. Reprod. Genet. 2013, 30, 813-819. [CrossRef]

118. Oates, R.D.; Silber, S.; Brown, L.G.; Page, D.C. Clinical characterization of 42 oligospermic or azoospermic men with microdeletion of the AZFc region of the $Y$ chromosome, and of 18 children conceived via ICSI. Hum. Reprod. 2002, 17, 2813-2824. [CrossRef]

119. De Vries, J.W.; Repping, S.; Oates, R.; Carson, R.; Leschot, N.J.; van der Veen, F. Absence of deleted in azoospermia (DAZ) genes in spermatozoa of infertile men with somatic DAZ deletions. Fertil. Steril. 2001, 75, 476-479. [CrossRef]

120. Schmidt, K.L.; Larsen, E.; Bangsbøll, S.; Meinertz, H.; Carlsen, E.; Andersen, A.N. Assisted reproduction in male cancer survivors: Fertility treatment and outcome in 67 couples. Hum. Reprod. 2004, 19, 2806-2810. [CrossRef]

121. Gandini, L.; Sgrò, P.; Lombardo, F.; Paoli, D.; Culasso, F.; Toselli, L.; Tsamatropoulos, P.; Lenzi, A. Effect of chemo- or radiotherapy on sperm parameters of testicular cancer patients. Hum. Reprod. 2006, 21, 2882-2889. [CrossRef] [PubMed]

122. Van der Kaaij, M.A.; van Echten-Arends, J.; Simons, A.H.; Kluin-Nelemans, H.C. Fertility preservation after chemotherapy for Hodgkin lymphoma. Hematol. Oncol. 2010, 28, 168-179. [CrossRef] [PubMed]

123. Cortes, D.; Thorup, J.M.; Visfeldt, J. Cryptorchidism: Aspects of fertility and neoplasms. A study including data of 1335 consecutive boys who underwent testicular biopsy simultaneously with surgery for cryptorchidism. Horm. Res. 2001, 55, 21-27. [CrossRef]

124. Zorn, B.; Virant-Klun, I.; Drobni, S.; Sinkovec, J.; Meden-Vrtovec, H. Male and female factors that influence ICSI outcome in azoospermia or aspermia. Reprod. Biomed. Online 2009, 18, 168-176. [CrossRef]

125. Desai, N.; Gill, P.; Tadros, N.N.; Goldberg, J.M.; Sabanegh, E.; Falcone, T. Azoospermia and embryo morphokinetics: Testicular sperm-derived embryos exhibit delays in early cell cycle events and increased arrest prior to compaction. J. Assist. Reprod. Genet. 2018, 35, 1339-1348. [CrossRef]

126. Loutradi, K.E.; Tarlatzis, B.C.; Goulis, D.G.; Zepiridis, L.; Pagou, T.; Chatziioannou, E.; Grimbizis, G.F.; Papadimas, I.; Bontis, I. The effects of sperm quality on embryo development after intracytoplasmic sperm injection. J. Assist. Reprod. Genet. 2006, 23, 69-74. [CrossRef]

127. Janny, L.; Menezo, Y.J. Evidence for a strong paternal effect on human preimplantation embryo development and blastocyst formation. Mol. Reprod. Dev. 1994, 38, 36-42. [CrossRef]

128. Ron-el, R.; Nachum, H.; Herman, A.; Golan, A.; Caspi, E.; Soffer, Y. Delayed fertilization and poor embryonic development associated with impaired semen quality. Fertil. Steril. 1991, 55, 338-344. [CrossRef]

129. Shoukir, Y.; Chardonnens, D.; Campana, A.; Sakkas, D. Blastocyst development from supernumerary embryos after intracytoplasmic sperm injection: A paternal influence? Hum. Reprod. 1998, 13, 1632-1637. [CrossRef]

130. Göker, E.N.; Sendag, F.; Levi, R.; Sendag, H.; Tavmergen, E. Comparison of the ICSI outcome of ejaculated sperm with normal, abnormal parameters and testicular sperm. Eur. J. Obstet. Gynecol. Reprod. Biol. 2002, 104, 129-136. [CrossRef]

131. Vernaeve, V.; Tournaye, H.; Osmanagaoglu, K.; Verheyen, G.; Van Steirteghem, A.; Devroey, P. Intracytoplasmic sperm injection with testicular spermatozoa is less successful in men with nonobstructive azoospermia than in men with obstructive azoospermia. Fertil. Steril. 2003, 79, 529-533. [CrossRef]

132. Nicopoullos, J.D.; Gilling-Smith, C.; Almeida, P.A.; Ramsay, J.W. The results of 154 ICSI cycles using surgically retrieved sperm from azoospermic men. Hum. Reprod. 2004, 19, 579-585. [CrossRef] [PubMed]

133. Sakkas, D. Novel technologies for selecting the best sperm for in vitro fertilization and intracytoplasmic sperm injection. Fertil. Steril. 2013, 99, 1023-1029. [CrossRef] [PubMed] 
134. Gil, M.; Sar-Shalom, V.; Melendez Sivira, Y.; Carreras, R.; Checa, M.A. Sperm selection using magnetic activated cell sorting (MACS) in assisted reproduction: A systematic review and meta-analysis. J. Assist. Reprod. Genet. 2013, 30, 479-485. [CrossRef]

135. Antinori, M.; Licata, E.; Dani, G.; Cerusico, F.; Versaci, C.; d'Angelo, D.; Antinori, S. Intracytoplasmic morphologically selected sperm injection: A prospective randomized trial. Reprod. Biomed. Online 2008, 16, 835-841. [CrossRef]

136. Teixeira, D.M.; Hadyme Miyague, A.; Barbosa, M.A.; Navarro, P.A.; Raine-Fenning, N.; Nastri, C.O.; Martins, W.P. Regular (ICSI) versus ultra-high magnification (IMSI) sperm selection for assisted reproduction. Cochrane Database Syst. Rev. 2020, 2, Cd010167. [CrossRef]

137. Parrella, A.; Keating, D.; Cheung, S.; Xie, P.; Stewart, J.D.; Rosenwaks, Z.; Palermo, G.D. A treatment approach for couples with disrupted sperm DNA integrity and recurrent ART failure. J. Assist. Reprod. Genet. 2019, 36, 2057-2066. [CrossRef] [PubMed]

138. Xie, P.; Keating, D.; Parrella, A.; Cheung, S.; Rosenwaks, Z.; Goldstein, M.; Palermo, G.D. Sperm Genomic Integrity by TUNEL Varies throughout the Male Genital Tract. J. Urol. 2020, 203, 802-808. [CrossRef]

139. Quinn, M.M.; Jalalian, L.; Ribeiro, S.; Ona, K.; Demirci, U.; Cedars, M.I.; Rosen, M.P. Microfluidic sorting selects sperm for clinical use with reduced DNA damage compared to density gradient centrifugation with swim-up in split semen samples. Human. Reprod. 2018, 33, 1388-1393. [CrossRef]

140. Samuel, R.; Feng, H.; Jafek, A.; Despain, D.; Jenkins, T.; Gale, B. Microfluidic-based sperm sorting \& analysis for treatment of male infertility. Transl. Androl. Urol. 2018, 7, S336-S347. [CrossRef] 